Article

\title{
Antiphytoviral Activity of Sesquiterpene-Rich Essential Oils from Four Croatian Teucrium Species
}

\author{
Nada Bezić ${ }^{1}$, Elma Vuko ${ }^{1}$, Valerija Dunkić ${ }^{1, *}$, Mirko Ruščić ${ }^{1}$, Ivica Blažević ${ }^{2}$ and \\ Franko Burčul ${ }^{3}$
}

1 Department of Biology, Faculty of Science, University of Split, Teslina 12, 21000 Split, Croatia; E-Mails: bezic@pmfst.hr (N.B.); elma@pmfst.hr (E.V.); mrus@pmfst.hr (M.R.)

2 Department of Organic Chemistry, Faculty of Chemistry and Technology, University of Split, Teslina 10, 21000 Split, Croatia; E-Mail: blazevic@ktf-split.hr

3 Department of Biochemistry, Faculty of Chemistry and Technology, University of Split, Teslina 10, 21000 Split, Croatia; E-Mail: franko@ktf-split.hr

* Author to whom correspondence should be addressed; E-Mail: dunkic@pmfst.hr; Tel.: +385-21-385-133; Fax: +385-21-384-0086.

Received: 25 July 2011; in revised form: 12 September 2011 / Accepted: 14 September 2011 / Published: 21 September 2011

\begin{abstract}
The purpose of this study was to compare the essential oil profiles of four Croatian Teucrium species (Lamiaceae), as determined by GC and GC/MS, with their antiphytoviral efficiency. A phytochemical analysis showed that T. polium, T. flavum, T. montanum and T. chamaedrys are characterized by similar essential oil compositions. The investigated oils are characterized by a high proportion of the sesquiterpene hydrocarbons $\beta$-caryophyllene (7.1-52.0\%) and germacrene D (8.7-17.0\%). Other important components were $\beta$-pinene from T. montanum and $\alpha$-pinene from T. flavum. The investigated essential oils were proved to reduce lesion number in the local host Chenopodium quinoa Willd. infected with Cucumber Mosaic Virus (CMV), with reductions of $41.4 \%, 22.9 \%, 44.3 \%$ and $25.7 \%$, respectively.
\end{abstract}

Keywords: $\beta$-caryophyllene; CMV; Teucrium chamaedrys; Teucrium flavum; Teucrium montanum; Teucrium polium 


\section{Introduction}

In the flora of Europe the genus Teucrium (Lamiaceae) includes 49 species, of which 13 are widespread in the Croatian flora, including the four species studied in this paper: T. polium L., T. flavum L., T. montanum L. and T. chamaedrys L. [1-4]. The essential oils of several other species of the genus Teucrium, viz. T. stocksianum ssp. stocksianum [5], T. hyrcanicum [6], T. maghrebinum [7], T. montbtetii ssp. heliotropiifolium [8], T. scoridum [9] and T. salviastrum [4] have been previously investigated. These oils are characterized by the presence of sesquiterpenes such as caryophyllene, caryophyllene oxide, germacrene $\mathrm{D}, \alpha$-humulene, $\alpha$-muurolene, $(E)$ - $\beta$-farnesene and the monoterpene carvacrol. Due to the wide spectrum of biological activities displayed by the essential oils, these compounds are the subject of different researches. The multiple roles of the essential oils and their main components make them natural substances of great importance in several fields such as physiological function of growth, ecological function, development [10], resistance against diseases and insects [11]. They also posses antimicrobial, antiviral, antimycotic, antioxigenic, antiparasitic and insecticidal properties [12-16]. Regarding phytopathogenic viruses, various substances of natural and synthetic origin have been assessed for their antiphytoviral activity [17-20]. So far, only a few studies have revealed the antiphytoviral activity of pure essential oils [13,17,21,22]. Essential oil of Satureja montana L. ssp. variegata (Host) P.W. Ball as well as its dominant phenol compounds thymol and carvacrol applied simultaneously with the infecting virus, reduced the number of local lesions on both Tobacco Mosaic Virus (TMV) and Cucumber Mosaic Virus (CMV) infected plants [21]. Essential oil of Melaleuca alternifolia (Maiden\&Betche) was effective in reducing lesion number in TMV-infected plants [13], while Plectranthus tenuiflorus essential oil inhibited Tobacco Necrosis Virus (TNV) infection [17]. Essential oil from Mediterranean endemic plant Teucrium arduini L. showed inhibitory effect on the development of infections caused by TMV and CMV [22].

The aim of the study was to determine the volatiles of four Croatian grown Teucrium species and evaluate their antiphytoviral effects on the development of local lesions in CMV infected plants.

\section{Results and Discussion}

\subsection{Essential Oil Composition and Variability}

Water distilled essential oils from aerial parts of T. polium, T. flavum, T. montanum and T. chamaedrys, collected from different localities (Table 3) have been analysed by GC and GC/MS and 54 different compounds were identified: 33 from T. polium, 45 from T. flavum, 37 from oil of T. montanum and 21 from oil of T. chamaedrys, representing $95.3 \%, 97.3 \%, 99.5 \%$ and $98.3 \%$ of the total oil, respectively (Table 1). The yields of the essential oils isolated from plants while in flowering vegetative cycle were: $0.5 \%$ from $T$. polium, $0.4 \%$ from $T$. flavum and $T$. montanum and $0.3 \%$ from T. chamaedrys. The main constituents of the investigated essential oils of Teucrium species are as follows: in T. polium $\beta$-caryophyllene (52\%) and germacrene D (8.7\%); in T. flavum $\beta$-caryophyllene (23.1\%), germacrene D (15.3\%) and $\alpha$-pinene (10.5\%); in T. montanum germacrene D (17.2\%), $\beta$-pinene (12.3\%) and $\beta$-caryophyllene (7.1\%); in T. chamaedrys $\beta$-caryophyllene (47.6\%) and germacrene D (29.0\%). Our results thus show that the major compounds in all investigated essential oils were the sesquiterpene hydrocarbons $\beta$-caryophyllene and/or germacrene $\mathrm{D}$. 
Cavaleiro et al. [4] reached similar conclusion for endemic species T. salviastrum from Portugal. In the oil of T. polium ssp. capitatum from Crete [8] the most abundant compounds were caryophyllene and the monoterpene carvacrol. Carvacrol was absent in all investigated oils, but in our previous study of $T$. arduini essential oil carvacol was represented in an amount of $1.6 \%$ [22]. The composition of T. polium from Iran [23] was similar to the investigated oils of T. flavum and T. montanum regarding the content of $\alpha$ - and $\beta$-pinene. In the present study we also identified limonene as an important compound of essential oils of T. polium (5.9\%), T. flavum (7.9\%) and T. montanum (4.6\%). These monoterpenes were reported as the main constituents in the oil of T. chamaedrys ssp. chamaedrys from Iran [6]. In this study, in relatively high percentages, essential oil from $T$. flavum contained $\alpha$-pinene (10.5\%), $\beta$-pinene (8.4\%) and limonene (7.9\%), while T. montanum essential oil contained $\beta$-pinene $(12.3 \%)$ and limonene $(4.6 \%)$.

\subsection{Antiphytoviral Activity}

A comparison (t-test) of the mean number of lesions on the oil-treated Chenopodium quinoa plants with the corresponding control showed that essential oils isolated from the investigated Teucrium species significantly reduced CMV infections. The most effective in reducing local lesion number was oil of T. montanum (44.3\%), followed by T. polium (41.4\%), T. chamaedrys $(25.7 \%)$ and T. flavum (22.9\%) (Table 2). The common feature of all investigated oils is the presence of $\beta$-caryophyllene and germacrene $\mathrm{D}$ in relatively high percentages. Our previous investigation had confirmed that $\beta$-caryophyllene is effective in reducing CMV infection [22]. With the exception of $T$. montanum essential oil, the percentage of $\beta$-caryophyllene in the oil correlates with antiviral activity of the oil. Essential oil of $T$. montanum showed the strongest antiviral activity, although content of $\beta$-caryophyllene is lower when compared to the other three oils. The most abundant components from T. montanum essential oil, aside from $\beta$-caryophyllene, are germacrene $\mathrm{D}, \beta$-pinene and limonene and as such they can be suggested to be responsible for the better antiphytoviral effect observed. As a comparison, the previously reported essential oil of Satureja montana was an inhibitor of TMV and CMV with antiviral activity rates of $29.2 \%$ and $24.1 \%$, respectively [21]. Dominant components of this oil were the oxygenated monoterpenes thymol and carvacrol, while the investigated oils from Teucrium species are rich in sesquiterpenes. Comparing the percentages of inhibition, essential oils of T. polium and T. montanum showed significantly stronger antiviral activity against CMV than essential oil of S. montana [21]. Other literature data dealing with antiviral activity of essential oils do not compare composition of oils and their antiviral effectiveness. Essential oil of Melaleuca alternifolia was previously reported as an inhibitor of TMV [13], while essential oil of Plectranthus tenuifloru showed an inhibitory effect against Tobacco Necrosis Virus, Tobacco Mosaic Virus and Tomato Spotted Wilt Virus [17]. Our conclusion is that sesquiterpene-rich essential oils are potent inhibitors of CMV infection and natural substances with possible role in the control of plant virus diseases. 
Table 1. Phytochemical composition (\%) of essential oils of T. polium, T. flavum, T. montanum and T. chamaedrys.

\begin{tabular}{|c|c|c|c|c|c|c|c|}
\hline Component & $\begin{array}{c}\text { RI } \\
\text { VF-5MS }\end{array}$ & $\begin{array}{c}\text { RI } \\
\text { CP-Wax } 52 \\
\end{array}$ & T. polium & T. flavum & T. montanum & T. chamaedrys & Identification \\
\hline Monoterpene hydrocarbons & & & 6.3 & 28.4 & 24.4 & 3.9 & \\
\hline$\alpha$-Pinene & 938 & - & $\operatorname{tr}$ & 10.5 & 1.9 & 1.0 & $\mathrm{RI}, \mathrm{MS}, \mathrm{Co}-\mathrm{GC}$ \\
\hline Camphene & 962 & - & - & 0.1 & - & - & RI, MS \\
\hline$\beta$-Pinene & 982 & $<1200$ & 0.3 & 8.4 & 12.3 & 1.9 & RI, MS, Co-GC \\
\hline Myrcene & 992 & $<1200$ & 0.1 & 0.7 & 4.2 & 0.2 & RI, MS \\
\hline Limonene & 1032 & 1204 & 5.9 & 7.9 & 4.6 & 0.6 & $\mathrm{RI}, \mathrm{MS}, \mathrm{Co}-\mathrm{GC}$ \\
\hline (Z)- $\beta$-Ocimene & 1052 & 1218 & $\operatorname{tr}$ & 0.6 & 0.8 & 0.2 & RI, MS \\
\hline Terpinolene & 1089 & 1286 & - & 0.2 & 0.6 & - & RI, MS \\
\hline Oxygenated monoterpenes & & & 12.5 & 3.4 & 12.4 & 0.2 & \\
\hline Linalool & 1099 & 1548 & 1.9 & 1.5 & 3.6 & - & RI, MS, Co-GC \\
\hline$\beta$-Thujone & 1121 & 1438 & 5.7 & - & 0.3 & - & RI, MS, Co-GC \\
\hline trans-Pinocarveol & 1147 & - & - & 0.4 & 1.2 & - & RI, MS \\
\hline Camphor & 1151 & 1499 & 1.4 & - & 1.3 & - & $\mathrm{RI}, \mathrm{MS}, \mathrm{Co}-\mathrm{GC}$ \\
\hline Borneol & 1176 & 1719 & 1.4 & - & 1.6 & - & RI, MS, Co-GC \\
\hline Terpinen-4-ol & 1184 & 1611 & 0.2 & 0.2 & 1.5 & - & RI, MS \\
\hline Myrtenol & 1197 & 1782 & - & 0.6 & 1.2 & 0.2 & RI, MS \\
\hline$\beta$-Cyclocitral & 1223 & 1629 & - & 0.2 & - & $\operatorname{tr}$ & RI, MS \\
\hline Linalyl acetate & 1252 & 1553 & 0.8 & 0.3 & 0.5 & - & $\mathrm{RI}, \mathrm{MS}, \mathrm{Co}-\mathrm{Gc}$ \\
\hline Bornyl acetate & 1285 & 1570 & 1.1 & 0.2 & 0.2 & - & RI, MS, Co-Gc \\
\hline$\alpha$-Terpenyl acetate & 1349 & - & - & - & 1.0 & - & RI, MS \\
\hline Sesquiterpene hydrocarbons & & & 76.0 & 50.8 & 35.1 & 86.9 & \\
\hline$\alpha$-Copaene & 1377 & 1484 & 0.2 & 0.7 & - & 0.7 & RI, MS \\
\hline$\beta$-Bourbonene & 1383 & 1508 & 0.7 & 2.6 & 3.4 & 3.7 & RI, MS \\
\hline$\alpha$-Gurjunene & 1407 & 1520 & - & 0.3 & - & 0.2 & RI, MS \\
\hline
\end{tabular}


Table 1. Cont

\begin{tabular}{|c|c|c|c|c|c|c|c|}
\hline$\beta$-Caryophyllene & 1424 & 1585 & 52.0 & 23.1 & 7.1 & 47.6 & RI, MS, Co-GC \\
\hline$\beta$-Copaene & 1429 & - & 1.4 & 2.7 & - & 5.7 & RI, MS \\
\hline trans- $\alpha$-Bergamotene & 1433 & - & 4.1 & - & - & - & RI, MS \\
\hline$(Z)-\beta$-Farnesene & 1454 & 1639 & 4.3 & 2.1 & 2.9 & - & RI, MS \\
\hline$\alpha$-Humulene & 1456 & 1654 & 4.6 & - & - & - & RI, MS \\
\hline allo-Aromadendrene & 1465 & 1662 & - & 1.2 & - & - & RI, MS \\
\hline Germacrene D & 1481 & 1692 & 8.7 & 15.3 & 17.2 & 29.0 & RI, MS \\
\hline$\beta$-Bisabolene & 1494 & 1729 & $\operatorname{tr}$ & 1.8 & 1.8 & - & RI, MS \\
\hline$\delta$-Cadinene & 1517 & 1745 & $\operatorname{tr}$ & 1.0 & 2.7 & - & RI, MS \\
\hline Oxygenated sesquiterpenes & & & tr & 5.0 & 5.1 & 5.9 & \\
\hline Spathulenol & 1577 & 2101 & $\operatorname{tr}$ & 1.6 & 1.9 & $\operatorname{tr}$ & RI, MS \\
\hline Caryophyllene oxide & 1581 & 1955 & $\operatorname{tr}$ & 2.6 & 1.0 & 4.5 & RI, MS, Co-GC \\
\hline$\alpha$-Cadinol & 1655 & 2208 & $\operatorname{tr}$ & 0.8 & 2.2 & 1.4 & RI, MS \\
\hline Phenolic compounds & & & 0.1 & 1.1 & - & 0.6 & \\
\hline$p$-Vinylanisole & 1159 & - & - & 0.5 & - & - & RI, MS \\
\hline Methyl salicylate & 1194 & - & - & - & - & 0.3 & RI, MS \\
\hline$p$-Vinyl-guaiacol & 1312 & - & - & 0.2 & - & 0.1 & RI, MS \\
\hline Eugenol & 1370 & 2020 & 0.1 & 0.4 & - & 0.2 & RI, MS, Co-GC \\
\hline Carbonylic compounds & & & tr & 7.2 & 0.9 & 0.4 & \\
\hline$n$-Amyl isovalerate & 1113 & - & - & 3.7 & 0.5 & - & RI, MS \\
\hline 3-Octanol acetate & 1125 & 1376 & - & 0.4 & - & - & RI, MS \\
\hline Isobutyl hexanoate & 1155 & - & - & 0.4 & - & - & RI, MS \\
\hline Butylhexanoate & 1193 & - & - & 0.5 & - & - & RI, MS \\
\hline Hexyl isovalerate & 1245 & 1409 & - & 0.1 & - & - & RI, MS \\
\hline Isoamyl hexanoate & 1256 & 1457 & - & 1.6 & - & - & RI, MS \\
\hline
\end{tabular}


Table 1. Cont.

\begin{tabular}{|c|c|c|c|c|c|c|c|}
\hline $\begin{array}{l}\text { 6,10,14-Trimethyl-2- } \\
\text { pentadecanone }\end{array}$ & 1839 & 2113 & $\operatorname{tr}$ & 0.5 & 0.4 & 0.4 & RI, MS \\
\hline Hydrocarbons & & & 0.4 & 1.4 & 21.6 & 0.4 & \\
\hline Eicosane & 2000 & 2000 & - & - & 0.2 & - & RI, MS, Co-GC \\
\hline Heneicosane & 2100 & 2100 & $\operatorname{tr}$ & - & 1.0 & 0.4 & RI, MS, Co-GC \\
\hline Docosane & 2200 & 2200 & - & 0.1 & 1.9 & - & RI, MS, Co-GC \\
\hline Tricosane & 2300 & 2300 & $\operatorname{tr}$ & 0.2 & 2.8 & - & $\mathrm{RI}, \mathrm{MS}, \mathrm{Co}-\mathrm{GC}$ \\
\hline Tetracosane & 2400 & 2400 & - & 0.1 & 3.1 & - & $\mathrm{RI}, \mathrm{MS}, \mathrm{Co}-\mathrm{GC}$ \\
\hline Pentacosane & 2500 & 2500 & 0.2 & 0.3 & 3.3 & - & RI, MS, Co-GC \\
\hline Hexacosane & 2600 & 2600 & - & 0.1 & 3.4 & - & RI, MS, Co-GC \\
\hline Heptacosane & 2700 & 2700 & 0.1 & 0.3 & 2.7 & - & RI, MS, Co-GC \\
\hline Octacosane & 2800 & 2800 & 0.1 & 0.1 & 2.0 & - & $\mathrm{RI}, \mathrm{MS}, \mathrm{Co}-\mathrm{GC}$ \\
\hline Nonacosane & 2900 & 2900 & $\operatorname{tr}$ & 0.2 & 1.2 & - & RI, MS, Co-GC \\
\hline Total identified (\%) & & & 95.3 & 97.3 & 99.5 & 98.3 & \\
\hline Yield (\%) & & & 0.5 & 0.4 & 0.4 & 0.3 & \\
\hline
\end{tabular}

RI-identification by comparison to literature [24] and/or homemade library; MS-identification by NIST02 and Wiley 7 spectral databases; Co-GCidentification confirmed with reference compound; tr-traces (mean value below $0.1 \%$ ); - = not identified.

Table 2. Effect of Teucrium flavum, T. chamaedris, T. polium and T. montanum essential oils on CMV infectivity.

\begin{tabular}{lcc}
\hline \multicolumn{3}{c}{ Mean of L.L \pm SEM \% of inhibition } \\
\hline Control & $7.0 \pm 0.5$ & $/$ \\
$T$. polium & $4.1 \pm 0.3 *$ & 41.4 \\
$T$. flavum & $5.4 \pm 0.3 *$ & 22.9 \\
$T$. montanum & $3.9 \pm 0.4 *$ & 44.3 \\
$T$. chamaedrys & $5.2 \pm 0.4 *$ & 25.7 \\
\hline
\end{tabular}

Mean of L.L $=$ the mean number of local lesions; SEM = Standard Error Mean; * Significance reduction in disease compared with control ( $\mathrm{p} \leq 0.05)$. 


\section{Experimental}

\subsection{Plant Material}

Plant material was collected, as stated in Table 3, in the spring (June) of 2011. Voucher specimens are deposited at the herbarium of the Department of Biology, Faculty of Science, University of Split, Croatia [No.FNSMST 2011: 2, 3, 4 and 5].

Table 3. Display of the localities, coordinates, elevations and habitat types of the investigated species of the Teucrium genus.

\begin{tabular}{lclcc}
\hline $\begin{array}{l}\text { Locality in } \\
\text { Croatia }\end{array}$ & Plant species & \multicolumn{1}{c}{ Habitat Types } & $\begin{array}{c}\text { Coordinates: } \\
\text { Gauss-Krüger } \\
\text { (X,Y) }\end{array}$ & $\begin{array}{c}\text { Altidude } \\
\text { a.s.l. (m) }\end{array}$ \\
\hline $\begin{array}{l}\text { Elevations } \\
\text { between Trogir } \\
\text { and Prapatnica }\end{array}$ & T. polium & $\begin{array}{l}\text { Rocky grassland, once an } \\
\text { area affected by fire }\end{array}$ & $\begin{array}{l}\mathrm{X}=5598845 \\
\mathrm{Y}=4820965\end{array}$ & 277 \\
$\begin{array}{l}\text { Marjan, hill } \\
\text { above town Split }\end{array}$ & T. flavum & $\begin{array}{l}\text { Dry grasslands as. Querco } \\
\text { ilici-Pinetum halepensis } \\
\text { Loisel 1971 }\end{array}$ & $\begin{array}{l}\mathrm{X}=5614505 \\
\mathrm{Y}=4819218\end{array}$ & \multirow{2}{*}{158} \\
$\begin{array}{l}\text { Elevations } \\
\text { between Trogir } \\
\text { and Prapatnica }\end{array}$ & T. montanum & $\begin{array}{l}\text { Rocky grassland, once an } \\
\text { area affected by fire }\end{array}$ & $\begin{array}{l}\mathrm{X}=5598845 \\
\mathrm{Y}=4820965\end{array}$ & 277 \\
& & $\begin{array}{l}\text { Rocky grassland in } \\
\text { succession towards under- } \\
\text { growth and lower forest as. } \\
\text { Carpino orientali-Quercetum } \\
\text { virgilianae Trinajstić } 1987\end{array}$ & $\begin{array}{l}\mathrm{X}=5624263 \\
\mathrm{Y}=4826875\end{array}$ & 356 \\
\hline
\end{tabular}

\subsection{Isolation of Essential Oils}

Aerial parts of plants were dried in a shady place at room temperature for 10 days. Plant tops during flowering were used for the analysis of essential oil composition. Dried aerial parts of plant material $(100 \mathrm{~g})$ were subjected to hydrodistillation for $3 \mathrm{~h}$ in a Clevenger type apparatus. The obtained essential oil was dried over anhydrous sodium sulphate.

\subsection{Gas Chromatography and Mass Spectrometry (GC, GC/MS)}

Gas chromatography analyses were performed on gas chromatograph (model 3900; Varian Inc., Lake Forest, CA, USA) equipped with flame ionization detector, mass spectrometer (model 2100T; Varian Inc.), non-polar capillary column VF-5MS (30 $\mathrm{m} \times 0.25 \mathrm{~mm}$ i.d., coating thickness $0.25 \mu \mathrm{m})$ and polar CP Wax $52(30 \mathrm{~m} \times 0.25 \mathrm{~mm}$ i.d., coating thickness $0.25 \mu \mathrm{m})$. VF-5MS column temperature was programmed at $60{ }^{\circ} \mathrm{C}$ isothermal for $3 \mathrm{~min}$, and then increased to $246{ }^{\circ} \mathrm{C}$ at a rate of $3{ }^{\circ} \mathrm{C} \cdot \min ^{-1}$ and held isothermal for $25 \mathrm{~min}$. CP Wax 52 column temperature was programmed at $70{ }^{\circ} \mathrm{C}$ isothermal 
for $5 \mathrm{~min}$, and then increased to $240{ }^{\circ} \mathrm{C}$ at a rate of $3{ }^{\circ} \mathrm{C} \cdot \mathrm{min}^{-1}$ and held isothermal for $25 \mathrm{~min}$. Other chromatographic conditions were: carrier gas helium; flow rate $1 \mathrm{~mL} \cdot \mathrm{min}^{-1}$; injector temperature $250{ }^{\circ} \mathrm{C}$; volume injected $1 \mu \mathrm{L}$; split ratio $1: 20$; FID detector temperature $300{ }^{\circ} \mathrm{C}$. MS conditions: ionization voltage $70 \mathrm{eV}$; ion source temperature $200^{\circ} \mathrm{C}$; mass scan range: $40-350$ mass units.

\subsection{Data Analysis and Data Evaluation}

The individual peaks were identified by comparison of their retention indices (relative to $\mathrm{C}_{8}-\mathrm{C}_{40}$ $n$-alkanes for VF-5MS and CP Wax 52) to those from a homemade library, literature [24] and/or authentic samples, as well as by comparing their mass spectra with literature [24], Wiley 7 MS (Wiley, New York, NY, USA) and NIST02 (Gaithersburg, MD, USA) mass spectral databases. The homemade library was created from authentic compounds obtained commercially and from the main components of many essential oils obtained during our previous studies. The component percentages were calculated as mean values form the GC and GC-MS peak areas using the normalization method (without correction factors).

\subsection{Plant Host for Antiphytoviral Studies}

Seeds of Chenopodium quinoa Willd. were sown in trays containing Klasmann universal compost and maintained in a growth chamber $\left(26^{\circ} \mathrm{C}, 16: 8 \mathrm{~h}\right.$ light/dark cycle) with watering as required. When the seedlings were large enough to handle they were transplanted individually into perforated styrofoam which contained fresh compost for ten days and then into $10 \mathrm{~cm}$ plastic pots with fresh compost. Plants were grown in a growth chamber under same conditions. Experimental plants were selected three to four weeks after sowing, when they had eight true leaves. Care was taken to ensure that the experimental plants were as uniform in size as possible.

\subsection{Solution of Essential Oil}

Spray solution containing $500 \mathrm{ppm}$ of essential oil in distilled water was prepared for testing the antiphytoviral effect. To overcome insolubility of the oil in water $0.05 \mathrm{~mL}$ of Tween 80 was mixed with $25 \mu \mathrm{L}$ of the oil and $50 \mathrm{~mL}$ of distilled water. Prepared solution was immediately sprayed to the test plants.

\subsection{Viral Inoculums}

Viral inoculum was prepared from leaf tissue obtained from Nicotiana megalosiphon Van Heurck \& Muell. Arg. plants previously infected with Cucumber Mosaic Virus (CMV). Leaves of systemically infected leaf material (3-5) were ground with $10 \mathrm{~mL}$ of inoculation buffer $(0.06 \mathrm{~mol} / \mathrm{L}$ phosphate buffer, $\mathrm{pH}=7.0$ ) in a mortar. Sap extract was diluted with the same inoculation buffer to give a suitable number of discrete local lesions on test plants. The inoculum prepared in this way was used to inoculate local host Chenopodium quinoa. 


\subsection{Application to the Local Host Plants}

Spray solution of essential oil was applied to Chenopodium quinoa plants for two successive days prior to CMV inoculation. Control spray was of distilled water and Tween 80. Plants were sprayed with either an oil or control solution. The second day of treatment plants were left to dry for $20 \mathrm{~min}$ and then inoculated with prepared viral inoculum. All treatments were repeated for three times on plants selected for uniformity and grown in a growth chamber $\left(26^{\circ} \mathrm{C} ; 16: 8 \mathrm{~h} \mathrm{light/dark}\right.$ cycle $)$. Local lesions were counted 6 th day post inoculation and the inhibition percentage was calculated by comparing the number of viral lesions on treated and control group according to the formula:

$$
I P=\frac{C K-A}{C K} \times 100
$$

where IP = antiviral inhibition in \%, CK = average number of viral lesions on the control group; $\mathrm{A}=$ average number of viral lesions on the essential oil treated group.

\subsection{Statistical Analysis}

The significance of difference between mean value for treatment and control was estimated statistically using one tailed Student t-test (GraphPad InStat software).

\section{Conclusion}

Our previous investigations as well as the investigation carried out in this study confirmed that essential oils are potent antiphytoviral agents. Based on the limited number of publications published so far in this field, it could be concluded that there is no universal mode of antiphytoviral action of essential oils. $\beta$-Caryophyllene, the main component of the investigated Teucrium oils, and known to be effective antiphytoviral agent, is responsible for the observed antiviral activity. However it is also possible that some other components, which may be present in very small quantities, contribute to its effectiveness. Some of the oil components are already known as antiphytoviral agents, but many others must be tested to answer the question about the antiphytoviral mechanism of essential oils.

\section{Acknowledgments}

This work was supported by research grants No. 177-1191192-0830 from the Ministry of Science Education and Sports of the Republic of Croatia.

\section{References}

1. Tutin, T.G.; Wood, D. Teucrium. In: Flora Europaea; Tutin, T.G., Ed.; Cambridge University Press: Cambridge, UK, 1972; Volume 3.

2. Nikolić, T., Ed.; Flora Croatica Database; Department of Botany, Faculty of Science, University of Zagreb: Zagreb, Croatia, 2011. Available online: http://hirc.botanic.hr/fcd (accessed on 25 July 2011).

3. Trinajstić, I. Plant Communities of Croatia; Academy of Forestry Sciences: Zagreb, Croatia, 2008; pp. 106-125. 
4. Cavalerio, C.; Salgueiro, L.R.; Antunes, T.; Sevinate-Pinto, I.; Barroso, G. Composition of the essential oil and micromorphology of trichomes of Teucrium salviastrum, an endemic species from Portugal. Flavour Fragr. J. 2002, 17, 287-291.

5. Hisham, A.; Pathare, N.; Al-Saidi, S. The Composition and Antimicrobial Activity of the Essential Oil of Teucrium stocksianum subsp. stocksianum Leaf from Oman. Nat. Prod. Comm. 2006, 1, 195-199.

6. Kazemizadeh, Z.; Basiri, A.; Habibi, Z. Chemical Composition of the Essential Oil of Teucrium hyrcanicum and T. chamaedrys L. subsp. chamaedrys from Iran. Chem. Nat. Comp. 2008, 44, 651-653.

7. Formisano, C.; Rigano, D.; Senatore, F.; Al-Hillo, M.R.Y.; Piozzi, F.; Rosselli, S. Analysis of Essential Oil from Teucrium maghrebinum Greuter et Burdet Growing Wild in Algeria. Nat. Prod. Comm. 2009, 5, 411-414.

8. De Martino, L.; Formisano, C.; Mancini, E.; De Feo, V.; Piozzi, F.; Rigano, D.; Senatore, F. Chemical Composition and Phytotoxic Effects of Essential Oils from Four Teucrium Species. Nat. Prod. Comm. 2010, 5, 1969-1976.

9. Morteza-Semnani, K.; Saeed, M.; Akbarzade, M. Essential oil composition of Teucrium scordium L. Acta Pharm. 2007, 57, 499-504.

10. Wink, M. Evolution of secondary metabolites from an ecological and molecular phylogenetic perspective. Phytochemistry 2003, 64, 3-19.

11. Gershenzon, J.; Dudareva, N. The function of terpene natural products in the natural world. Nat. Chem. Biol. 2007, 3, 408-414.

12. Michaelakis, A.; Theotokatos, S.A.; Koliopoulos, G.; Chorianopoulos, N.G. Essential oils of Satureja species: insecticidal effects on Culex pipens larvae (diptera: culicidae). Molecules 2007, 12, 2567-2578.

13. Bishop, C.D. Antiviral activity of the essential oil of Melaluca alternifolia (Maiden \& Betche) cheel (tea tree) against tobacco mosaic virus. J. Essent. Oil Res. 1995, 7, 641-644.

14. Juglal, S.; Govinden, R.; Odhav, B. Spice oils for the control of co-occurring mycotoxinproducing fungi. J. Food Prot. 2002, 65, 683-687.

15. Moon, T.; Wilkinson, J.M.; Cavanagh, H.M.A. Antiparasitic activity of two Lavandula essential oils against Giardia duodenalis, Trichomonas vaginalis and Hexamita inflata. Parasitol. Res. 2006, 99, 722-728.

16. Lamiri, A.; Lhaloui, S.; Benjilali, B.; Berrada, M. Insecticidal effects of essential oils against Hessian fly, Mayetiola destructor (Say). Field Crop. Res. 2001, 71, 9-15.

17. Othman, B.A.; Shoman, S.A. Antiphytoviral Activity of the Plectranthus tenuiflorus on Some Important Viruses. Int. J. Agri. Biol. 2004, 6, 844-849.

18. Krcatović, E.; Rusak, G.; Bezić, N.; Krajačić, M. Inhibition of Tobacco Mosaic Virus infection by quercetin and vitexin. Acta Virolog. 2008, 52, 119-124.

19. Rusak, G.; Krajačić, M.; Pleše, N. Inhibition of tomato bushy stunt virus infection using a quercetagetin flavonoid isolated from Centaurea rupestris L. Antiviral Res. 1997, 36, 125-129.

20. Yordanova, A.; Korparov, N.; Stomenova, E.; Starcheva, M. Antiphytoviral activity of 1-morpholinomethyl tetrahydro 2-Pyrimidinone (DDB). Plant Pathol. 1996, 45, 547-551. 
21. Dunkić, V.; Bezić, N.; Vuko, E.; Cukrov, D. Antiphytoviral Activity of Satureja montana L. ssp. variegata (Host) P. W. Ball Essential Oil and Phenol Compounds on CMV and TMV. Molecules 2010, 15, 6713-6721.

22. Dunkić, V.; Bezić, N.; Vuko, E. Antiphytoviral Activity of Essential Oil from Endemic Species Teucrium arduini L. Nat. Prod. Comm. 2011, 6, 1385-1388.

23. Maghtader, M. Chemical Composition of the Essential Oil of Teucrium polium L. From Iran. Amer.-Euroas. J. Agric. Environ. Sci. 2009, 5, 843-856.

24. Adams, R.P. Identification of Essential Oil Components by Gas Chromatography/Mass Spectroscopy, 4th ed.; Allured Publishing Corporation: Carol Stream, IL, USA, 2007.

Sample Availability: Samples of the compounds are available from the authors.

(C) 2011 by the authors; licensee MDPI, Basel, Switzerland. This article is an open access article distributed under the terms and conditions of the Creative Commons Attribution license (http://creativecommons.org/licenses/by/3.0/). 